LOCAL WISDOM, 12 (1): 31-45, 2020
Local Wisdom Scientific Online Journal
ISSN: $2086-3764$

\title{
Visual Character of Colonial Building Facade in Suroyo Street Corridor, Probolinggo City Indonesia
}

\author{
Adita Ronarizkia $^{1^{*}}$, Novi Sunu Sri Giriwati ${ }^{2}$ \\ ${ }^{1}$ Magister Architecture, Faculty of Engineering, Brawijaya Univerrsity, Indonesia \\ 2 Department of Architecture, Faculty o Engineering, Brawijaya University, Indonesia \\ Corresponding Author: : adita.aditarona@gmail.com
}

\begin{tabular}{|c|c|}
\hline & Abstract \\
\hline $\begin{array}{l}\text { Keywords: } \\
\text { Colonial Building, } \\
\text { visual character, } \\
\text { building facade }\end{array}$ & $\begin{array}{l}\text { Suroyo street corridor located in the City of Probolinggo is one of the } \\
\text { central areas of the Dutch government that has several conservation } \\
\text { buildings as a historical identity of the city. Colonial buildings in this } \\
\text { location have various facades that are able to describe the visual } \\
\text { characteristics of the historic area. However, there were } \\
\text { developments that affect the modernity of the region by changing } \\
\text { colonial buildings into other functions and changing some facade } \\
\text { elements which will certainly eliminate some of the visual } \\
\text { characteristics of colonial building facades on each building. The } \\
\text { purpose of this study is to classify the facade forming elements and } \\
\text { get the dominant form in each element that forms the facade of the } \\
\text { remaining colonial buildings, so it wouldn't lose the overall visual } \\
\text { character of the colonial building facade and to be able to respond to } \\
\text { the development of a more directed and controlled. The method that } \\
\text { were used is descriptive qualitative methods by selecting samples } \\
\text { using purposive sampling, then proceed with data collection through } \\
\text { field observations and interviews to obtain relevant information and } \\
\text { analysis by classifying building masses, walls, roof elements, doors, } \\
\text { windows and facade symmetry. The results showed the visual } \\
\text { character of the colonial building with the style of De Stilj with the } \\
\text { classification of the dominance of a single mass, roof shield, paint } \\
\text { plaster brick walls, double-paneled doors, double-windowed grating, } \\
\text { and the symmetrical shape of the building facade. }\end{array}$ \\
\hline
\end{tabular}

DOI: https://doi.org/10.26905/lw.v12i1.3833

@ 2017 The Authors. Published by GKAK UNMER Malang

*Corresponding Author: adita.aditarona@gmail.com

\section{Introduction}

The Probolinggo is a city known as the Dutch colonial occupation in 1743. Probolinggo has a strategic location that is located between the coast and the fertile highlands. So, from this location it is able to produce abundant natural resources and become a special attraction for the needs of the Dutch government to occupy the city. The existence of coastal areas and plateaus is then connected so that it becomes a major axis. That 


\section{Adita Ronarizkia Novi Sunu Sri Giriwati}

major axis area is used by the Dutch as the center of government. One of the areas that became the center of the Dutch government was named Heerenstraat or now called Jalan Suroyo Kota Probolinggo (Handinoto, 1997) and (Wiyatno, 2014). The Suroyo street corridor is the main axis of Probolinggo City which connects the coastal area with the highlands. When the Dutch colonial period this street corridor became the center of government and many left some buildings that are still preserved today. According to Wiyatno's previous research, 2014 historic buildings in the center of Probolinggo which are still preserved are mostly located on Jalan Suroyo as the city axis. This building is a proof of history in the past. Dutch heritage buildings are called colonial buildings that were built during the Dutch government. Colonial architecture was a mixtured of Dutch architectural styles, Javanese styles and Indonesia's tropical climate styles. At that time, the style of buildings contained in the central office and residential areas of Europeans, namely the Indishe Empire Style. This building style then underwent a process of adaptation to the development of a more modern colonial style in the 20th century. These forms were still coloring the region. This could be seen from the shape of the column that was originally a classical style and then turned into a cast stone column (Thamrin, 2010). According to Estin (2016), Dutch colonial buildings in Indonesia have distinctive features, namely balanced (symmetrical), high ceilings, thick walls, shielded roofs with dimensions of doors and windows that are large enough, and colors that tend to be white. Other Dutch building styles from before and after experiencing development could be classified into several building styles, including: (1) Indische Empire Style, (2) Voor 1900, (3) NA 1900, (4) Romantiek, (5) 1915s, (6) 1930s (Amsterdam School, De Stilj) (7) Gothic (Handinoto, 2010) and (Hadi Dharma, 2014). Each style of Dutch colonial building has a different character and deserves to be preserved as a cultural heritage building to the present.

Along with the times, the architectural style of Dutch colonial buildings has changed on its character. This changed character could occur in the entire building both the exterior and interior of the building. The most influential part of the change is the building facade. The building facade is an element describing the identity of each building that can be visually observed. This is also reinforced by the statement of Krier (2001) which revealed that the facade is one of the important aspects in describing the visual character of the building. The character formed in each building will produce characteristics as the identity of the building to distinguish between one building with another building (Fajarwati, 2011).

The characters contained in building facades could express the function, meaning, culture, and historical value of each building (Sukarno, 2014). The building facade element consists of three important parts, namely the head (roof of the building), parts of the body (walls, window doors, bouvenlincth, etc.) and feet (floor) (Krier, 2001). In addition, according to Estin (2016) stated that the visual character of the building facade can be viewed from the mass of the building, wall elements, roofs, columns, doors, and windows. The shape of each facade element is what distinguishes the character of colonial buildings from one another. The visual character of the colonial building facades that remains in the historic street corridor were expected to be able to represent history in the past that can be preserved until the future.

Therefore, in facing the development of the age and preventing changes in character that were not controlled and not directed, it is necessary to study the visual character of the facade of a colonial building as a basic reference for colonial buildings in the maintenance and cultural inheritance going forward. In addition, this study also revealed factors that influenced changes in the visual character of the colonial building facade in the Suroyo corridor in Probolinggo City. 


\section{Literature Review}

Colonial style buildings are building styles that have developed in countries around America and Europe (Handinoto, 1996). Colonial buildings are identical with the buildings of the past that are implied by the process of adaptation between two nations. The formation of colonial buildings in Indonesia is also through a process of adaptation to climate, material and local cultural differences (Kurniawan, 2017).

Dutch colonial architecture was a development in the early 19th century until 1920 in Indonesia. The architectural style that emerged at that time was mixed between traditional architecture and western architecture, so that some Dutch colonial buildings adapted local traditional elements, such as Java. Then the application to the architectural form and develop in Indonesia (Soekiman, 2000). The following Dutch colonial architectural style of buildings expressed by Handinoto (2010), including (1) Indische Empire Style, has the shape of the roof used is a shield roof, a monumental memorable building, and a large yard, (2) Voor 1900, a form which has the addition of space-forming elements using corrugated zinc material and supported by cast iron columns, (3) NA 1900, the column has begun to narrow even disappear and there are already symmetrical buildings, (4) Romantiek, has the character of the addition of many decorative ornaments to all elements and shapes, (5) In the 1915s, the use of decorative details had greatly diminished and was still influenced by previous patterns, like Indische Empire Style, NA 1900, Voor 1900, (6) In the 1930s, the influence of vernacular architecture was quite large and there was a play of the shape of a cube with brick or concrete material both used for roofs, tritisan and for building bodies.

Each of these colonial building styles will later form a distinct character that is different from the character of colonial buildings in other areas. Character is a sign or a collection of several characteristics in introducing a building. Recognition and observation of a character using the five senses in the form of the sense of sight, this is what is often referred to as the visual system (Sudarwani, 1972). Therefore, the visual character of a building is what expresses a collection of physical characteristics of a building through observation.

Physical building can be reviewed through two aspects, namely the interior and exterior of the building. However, the most influential thing in visual character is the exterior facade of the building. The building facade consists of several elements, including: roof, walls, doors, windows, bouvenlincth, and floors (Krier, 2001). Meanwhile, according to Estin (2016) in expressing the physical characteristics of building facades can be seen from the shape and mass of the building, the elements of walls, roofs, columns, doors, and windows, each of which is examined regarding the shape, type and material.

The process of analyzing the visual character of colonial building facades in an area can be assessed between the relationship of buildings to each other using the parameters of dominance. This dominance is a parameter that is seen from the visual aspect that is striking and interesting between one building with another (Misavan, 2014). Disclosure of visual characters contained in an area in terms of time periods will produce different characters. The difference in character is produced due to some changes and developments. This change can occur in the form of addition, subtraction or transfer of buildings. Changes to the physical elements of this building can be caused by several factors, including factors that originate from the community (new discoveries, conflicts, and increasing or decreasing population) and from factors outside the community (natural environment, climate and other cultural influences). Factors originating from the community generally occur because of changes in the level of needs each year and changes in building owners (Kurniawan, 2015). 


\section{Visual Character of Colonial Building Facade in Suroyo Street Corridor, Probolinggo City Indonesia}

Adita Ronarizkia Novi Sunu Sri Giriwati

\section{Methodology}

This study was carried out on Jalan Suroyo, Kelurahan Sukabumi, Mayangan District, Probolinggo City which is the main axis of the city to date. Jalan Suroyo Corridor as the main axis of the city and the center of Dutch government in the past has a length of \pm 950m and width of $\pm 5 \mathrm{~m}$ which borders directly with the City Square Probolinggo. The remaining Dutch colonial buildings in the corridor of the road are used as research objects by selecting using purposive sampling techniques based on criteria regarding the ease of licensing and the quality of buildings that are still maintained. The total number of colonial buildings selected as research samples were 10 colonial buildings out of a total of 12 buildings. (Figure 1)

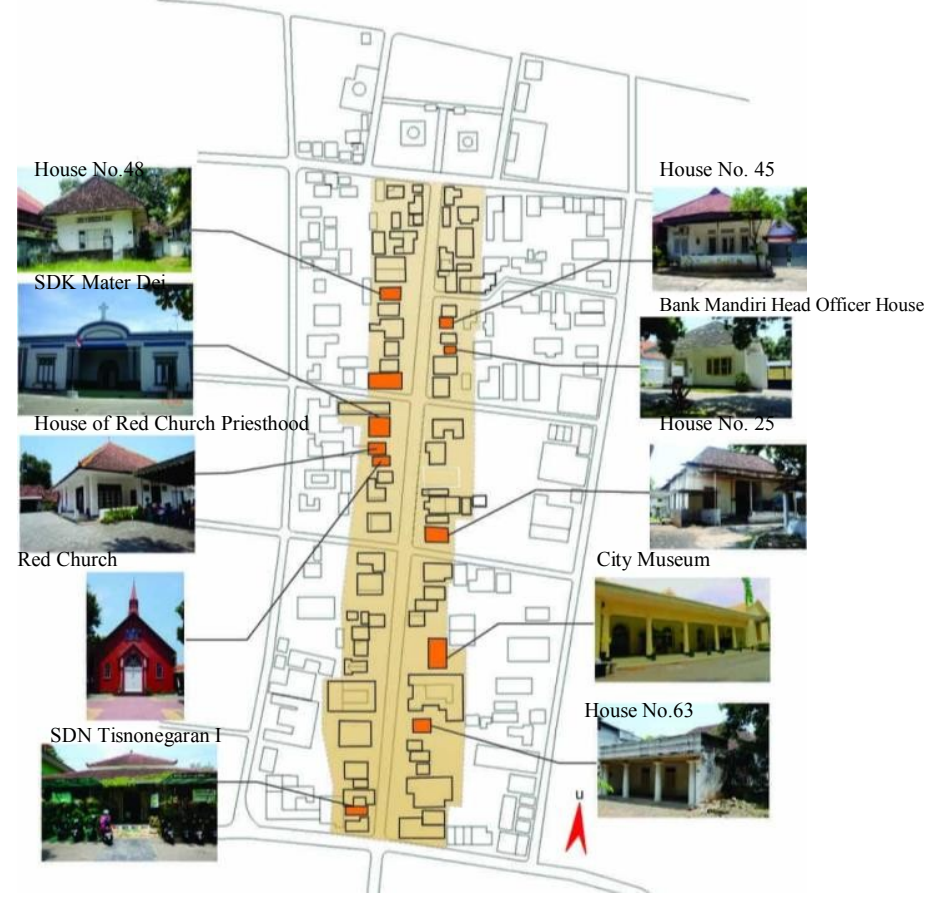

Figure 1. Colonial Building on Suroyo Street, Probolinggo City

The method used in this research was a qualitative descriptive method in visualizing and describing the elements that make up the building facade. Then, proceed with the analysis process of each building element until it could be concluded the visual character of the Dutch colonial building facade on Jalan Suroyo, Probolinggo City. The stages of the study began with the process of collecting data through field observations and interviews with building owners. Other data and information were also obtained from several previous studies on similar research topics and loci. This previous research was also used as a material consideration in determining research variables that are adjusted to field conditions. The research variables and sub-variables making up the facade used, namely the mass of the building (shape and proportion of buildings), walls (material and color), roof (roof shape, roof slope, and roof material), columns, doors, windows with sub variable shapes or the type, material and color used) (Estin, 2016b) and (Sukarno, 2014). Based on the results of the elaboration of each characteristic in facade elements, an analysis of the building style or style of the Dutch colonial architecture and facade symmetry of each building were carried out (Piutanti, 2019) and (Cahyani, 2014). In addition to revealing the visual character of the facades of each building, the analysis process was also accompanied by changes that occur from each visual element of the building facade and factors that affect 
changes in visual character in the corridor of the road.

\section{Result and Discussion}

The visual character of the building facade was certainly directly related to each element forming the building facade starting from the mass of the building, roof, columns, doors, windows, and symmetrical facades. All of these components would form an identity or a separate character that could be classified in the type of building style.

\section{Visual Character based on Facades Elements}

The visual character of building facades could be seen through a number of predetermined indicators, including building mass, walls, columns, doors, windows, and symmetrical facades.

\section{The Building Mass}

The colonial building in the Suroyo road corridor of Probolinggo City has a mass of buildings dominated by rectangular single buildings that have an average height of one floor. The proportion of colonial buildings owned by each building on average has a greater ratio on the horizontal side or width of the building compared to the vertical side of the building height. However, there were also one of the colonial buildings that has a higher proportion of height because it has a tower, the Red Church with a worship function. The height of each building is not far from the width of the building. Based on observations of the height owned by each Dutch colonial building in this corridor road is higher than the height of one-story buildings in general. This illustrates the characteristics of Dutch colonial buildings that have high ceilings. Here are a few buildings that can represent each function. (Figure 2)
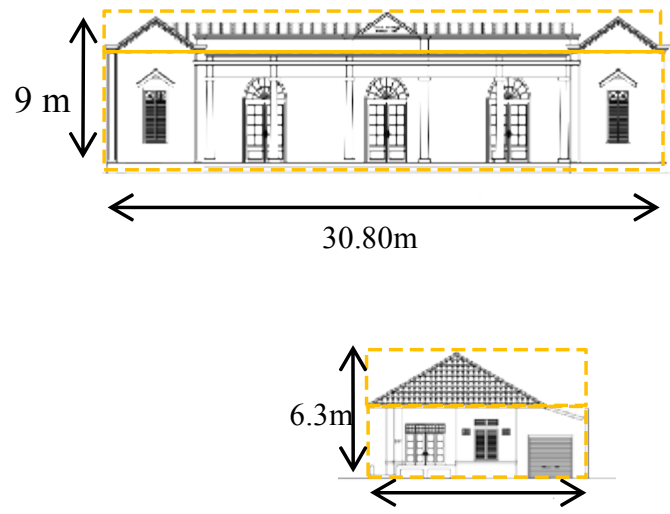

$10.95 \mathrm{~m}$

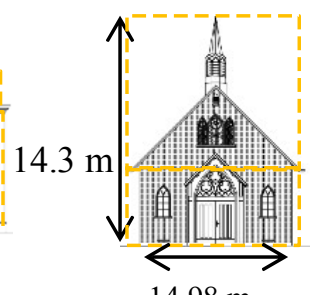

$14.98 \mathrm{~m}$

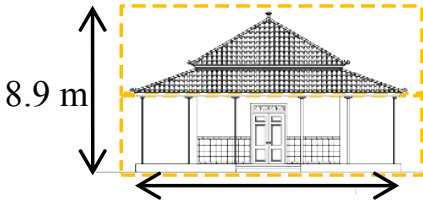

$10.25 \mathrm{~m}$

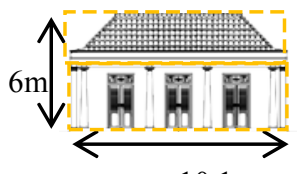

Figure 2. Some objects of the mass of Dutch colonial buildings on Jalan Suroyo, Probolinggo City 
The mass of colonial buildings in the corridor of this road did not experience significant changes, it could be said that the mass of the building is still in its original condition. It is happen because the government has determined these buildings as cultural heritage buildings that must be preserved, so that the building owner also maintains the shape of the mass without adding or reducing the mass of the building.

\section{The Roof}

The roof element in the colonial building on Jalan Suroyo in Probolinggo City has reflected its characteristics as a Dutch heritage building that is dominated by the shape of the shield roof. The type of roof shielding comes from the adaptation of Javanese roofs that has a roof slope of $\pm 30^{\circ}-60^{\circ}$. The entire colonial building on Jalan Suroyo contained six buildings with shielding roofs, and one of the buildings had a double shielding roof which also adapted the shape of the roof of a traditional Javanese house called Joglo. The material used for the roof shield in the corridor is entirely made of clay tile.

In addition, some buildings also have other types of roofs, such as saddle roofs with a slope angle of $\pm 45^{\circ}-60^{\circ}$ at the Red City Church of Probolinggo and flat roofs on the SDK Mater Dei building. The two buildings that have gable roofs use tiled zinc material. Meanwhile, for flat roofs on SDK Mater Dei use concrete cast material. Although the shape of the roof used varies between buildings, but the dominance of the roof that is used from the whole building remains the shape of the shield roof which is the character of the Dutch heritage building. (Figure 3).
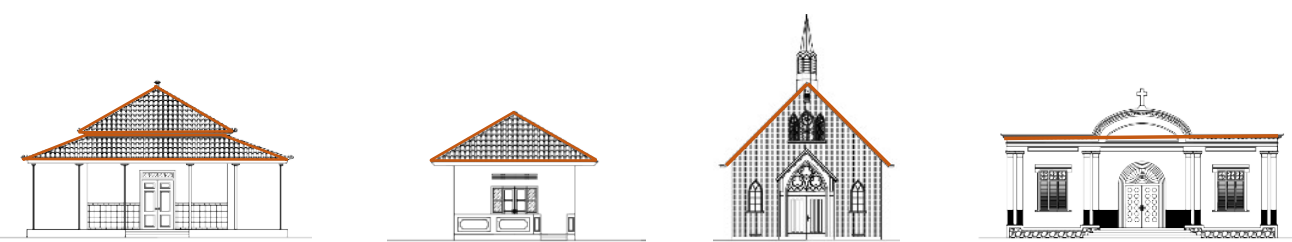

Figure 3. Several forms of the roof of the Dutch colonial building on Jalan Suroyo, Probolinggo City

The shape of the roof elements in the colonial building in the Suroyo corridor of Probolinggo City has not changed until now. However, there were some buildings that occur additions such as tritisan to shade the terrace in front of the building, such as in house building no. 25, while other buildings are still using the same type of roof as the original and only renovating the roof material. (Figure 4).

a) $\mid$

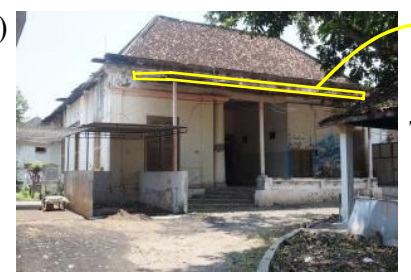

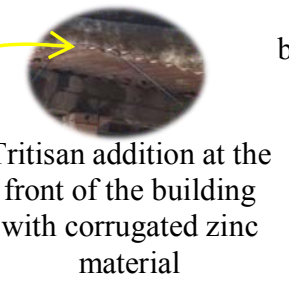

b)

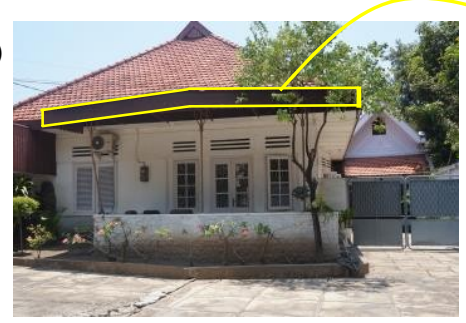

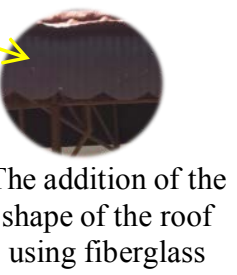

using fiberglass

Figure 4. Adding roof of building (a) House No. 25 (b) House No. 45The Wall

The wall element in this research is the exterior wall part only. The walls used in most of the colonial buildings in the corridor at Jalan Suroyo Kota Probolinggo were walls with plaster and painted brick material which has a thickness of $\pm 15 \mathrm{~cm}$. But there were also buildings that use walls with corrugated zinc alloy material with a thickness of $\pm 0.25 \mathrm{~mm}$, such as the walls of the Red Church of the City of Probolinggo with a mixture of red paint. (Figure 5) 
Changes visually on the walls of colonial buildings in this area occured only in some buildings only. Changes that occured not only change the color, but there was one building that adds a ceramic material on the brick wall plaster with interest will be resistance to humidity temperature can cause mold. (Figure 5). This is because the adjustment of individual desire of the owner of the building and adjusts the functional requirements and conditions. However, the entire colonial building objects in the corridor remained dominated by plaster brick walls. This is appropriate with the characteristic of Dutch heritage buildings were dominant with a brick.
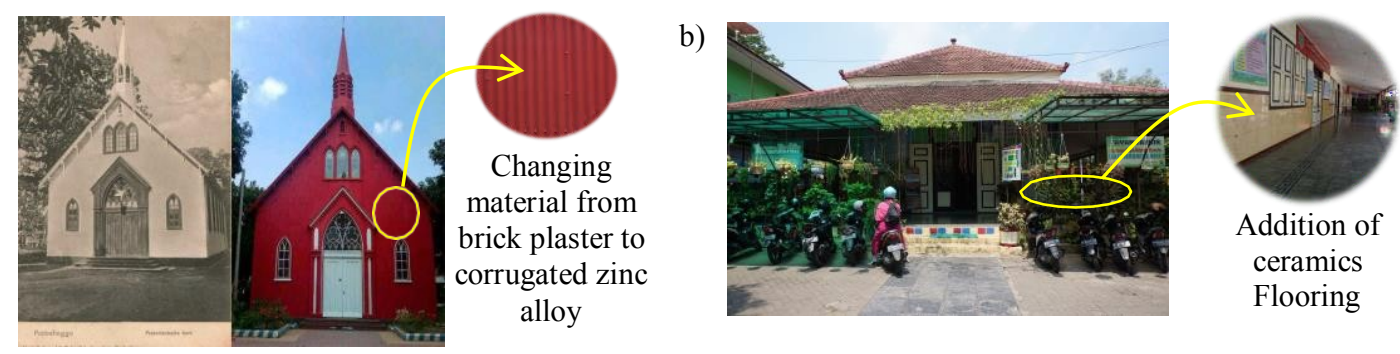

Figure 5. Changes in Wall Material in colonial buildings in (a) Red Church (b) Tisnonegaran I Elementary School Office

Source : (a) https://rendriapril.blogspot.com/

\section{The Column}

The column used to see the visual character of a building is the column located on the exterior. The exterior column of the building in the Suroyo corridor of Probolinggo City has a fairly simple shape or it is not patterned and tends to be plain. The shape of colonial buildings which have columns are mostly round. The columns used also vary depending on the style of each building. The Indische Empire Style building has round columns and is perpendicular to the floor of the building which is a Neoclassical stone pillar. There was also the shape of a kind of column that is rounded conical upwards and made of cement stone material (plaster stone) called the Neoclassical stone pillars in Korinthia style. The ornamentation that belongs to this type of column is only found on the head (capital) and the foot of the looping column is square for the perpendicular column and the loop is round for the conical round column.

Different building styles also produce different column shapes. De Stilj building style (1930s) which has a round column shape with a smaller size and elongated with steel material. This column is in the style of the Tisnonegaran I Elementary School building as a roof support. This column element is also closely related to the harmony of the wall, therefore in terms of visual column also often changes in several buildings. Changes that occur in this column element, the color of the paint that adjusts to other elements. One of them happened in the Probolinggo City Museum building which changed the color of the paint on the elements of the walls and the columns that match the theme, so the color of the columns that were originally white turned into orange or bright colors. However, the dominance of the use of columns with neoclassical forms reflects the visual character of the columns from colonial buildings from the Netherlands.

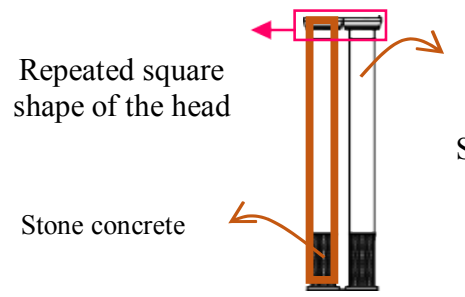

Stone Plaster
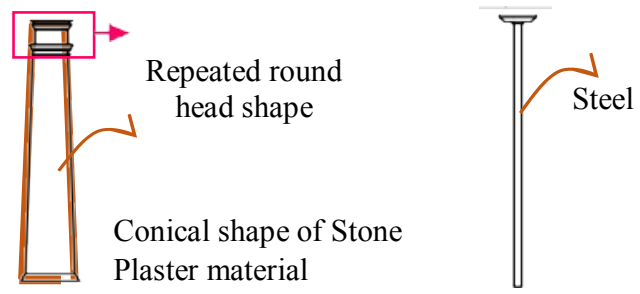


\section{Visual Character of Colonial Building Facade in Suroyo Street Corridor, Probolinggo City \\ Indonesia}

Adita Ronarizkia Novi Sunu Sri Giriwati

Figure 5. Form a column of several Colonial Buildings on Jalan Suroyo, Probolinggo City

\section{The Door}

The exterior doors of the colonial building in the corridor of Jalan Suroyo in Probolinggo City were dominated by double-leaf doors that coincide in the era of 20th-century architectural development. This double door also has several types, namely double paneled and latticed doors. The type of door that is widely used in buildings in this corridor is wood paneled double doors. The number of buildings that have a type of wooden paneled double doors are five buildings, including the Tisnonegaran I SDN office, Red Church, SDK Mater Dei, house no. 48, and house no. 25. In addition to this type of door, there were also some that combine with other materials, namely a combination of wood and glass, such as the Red House priest's official building, Probolinggo City Museum, the official residence of the Head of Bank Mandiri, and house no. 45 which uses a type of stained glass. The other door forms are the form of a double leaf door with a lattice for the sake of natural ventilation into the building. This is found in house building no. 63. The character of the paneled double doors with \pm 2.5 meter door height reflects the character of the old Dutch colonial buildings.

The overall shape of the door is also closely related to the vent that blends with the door element. The vents that are owned by each building are certainly different, but the type of vents that are often used in buildings in the corridor of this road is a rectangular geometry. Other forms of ventilation above the door element are only carvings on glass which symbolize a certain meaning adjusting the function of each building, such as carvings on the Red Church and SDK Mater Dei.

Door elements also experience changes in some buildings, namely the color and material. The color of the door leaf changes in harmony with other facade elements according to the interests of the owner or the building manager, such as the Probolinggo City Museum which changes the color of the door from white to orange to adjust the color of the walls and columns. Other changes also occur in house no. 45 which adds geometric shaped tralis made of iron for security purposes.
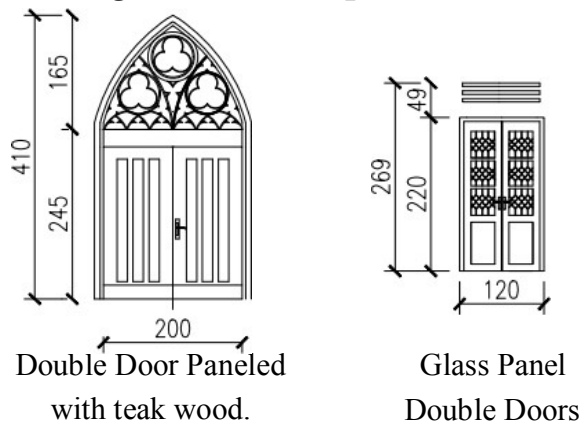

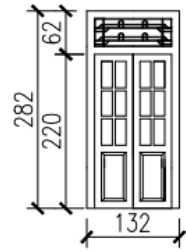

Stained Glass Panel Double

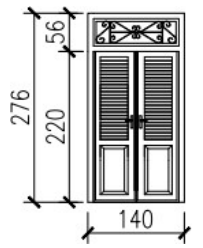

Double Door Paneled

Grating /Lattice

Figure 6. The door forms on several Colonial Buildings on Jalan Suroyo Kota Probolinggo 
5. The Window

The Dutch colonial building on Jalan Suroyo Kota Probolinggo has four types of windows which are generally quite large and tall even in line with the door. The facade of the building in the overall corridor is dominated by the type of double pane window pane that uses a combination of wood and glass. This type of window is one of the characteristics of Dutch colonial buildings. Other window types are double-double windows, single windows and triple windows. Double-double window is a window that has two layers with wooden materials in the form of panels and the second layer is in the form of a grating. Meanwhile, the type of single window has a shape that adjusts the style and elements of the door, as in the Red Church with Gothic style so that the single window is paneled with the type of arch at the top of the window and the materialial used is a combination of wood and colored stained glass. Another type of window is a triple or triple-leaf window. This type also has a grating shape with wood material. Based on the four types of windows used in colonial buildings in the corridor of this road all types of windows have a strong verticalization element with a height of up to \pm 2.5 meters for some types of windows.

The color of the window also affects the visual character that is formed in the building. The windows of the entire building must be aligned with the color of the door elements which are predominantly white for the colonial buildings in the area of the road. The white color is identical to the character of the Dutch building which is quite strong, although now there are some changes in some building functions.

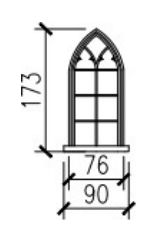

Single Window

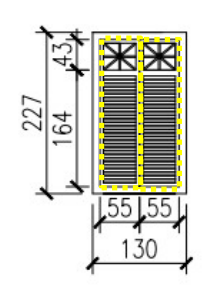

Double Window Lattice

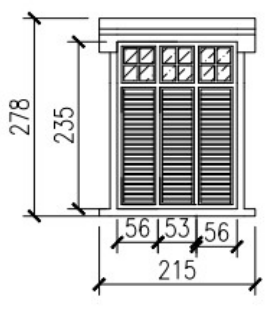

Triple Window

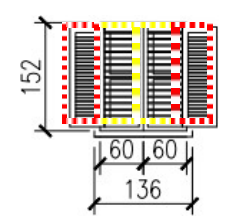

Double Duplex Window La

Figure 7. Windows form of several Colonial Buildings on Jalan Suroyo Kota Probolinggo

\section{The Façade of Symmetricity}

The symmetry of a building is closely related to Javanese dwellings, for that the Dutch colonial buildings in Indonesia were a process of adaptation of Javanese house architecture that prioritizes balance in structuring the building's facade. This is proven by the existence of a Dutch colonial building in the corridor of Jalan Suroyo, Probolinggo City, which is dominated by a rectangular mass shape that has a balance (symmetry) on the shape of the building, including the Museum of the City of Probolinggo, SDK Mater Dei, Red Church, SDN Tisnonegaran I office, house no. 48 , house no.45, house no.25, house no. 63, and the official residence of the head of Bank Mandiri. But there are also buildings that have asymmetrical forms such as the Red Church priest's official residence.

\section{The Façade of Symmetricity}

The symmetry of a building is closely related to Javanese dwellings, for that the Dutch colonial buildings in Indonesia were a process of adaptation of Javanese house architecture that prioritizes balance in structuring the building's facade. This is 


\section{Adita Ronarizkia Novi Sunu Sri Giriwati}

proven by the existence of a Dutch colonial building in the corridor of Jalan Suroyo, Probolinggo City, which is dominated by a rectangular mass shape that has a balance (symmetry) on the shape of the building, including the Museum of the City of Probolinggo, SDK Mater Dei, Red Church, SDN Tisnonegaran I office, house no. 48 , house no.45, house no.25, house no. 63, and the official residence of the head of Bank Mandiri. But there are also buildings that have asymmetrical forms such as the Red Church priest's official residence.

\section{The Façade of Symmetricity}

The symmetry of a building is closely related to Javanese dwellings, for that the Dutch colonial buildings in Indonesia were a process of adaptation of Javanese house architecture that prioritizes balance in structuring the building's facade. This is proven by the existence of a Dutch colonial building in the corridor of Jalan Suroyo, Probolinggo City, which is dominated by a rectangular mass shape that has a balance (symmetry) on the shape of the building, including the Museum of the City of Probolinggo, SDK Mater Dei, Red Church, SDN Tisnonegaran I office, house no. 48 , house no.45, house no.25, house no. 63, and the official residence of the head of Bank Mandiri. But there are also buildings that have asymmetrical forms such as the Red Church priest's official residence.

\section{Visual Character Facades based on Building Style}

The colonial government heritage building in Jalan Suroyo Kota Probolinggo has a variety of styles or styles that differ from one another. Building style is one of the parameters that can describe the visual characteristics of the overall colonial facade along the road corridor. The styles of colonial buildings in the Suroyo Street corridor are diverse, as has been classified in Table 1.

Table 1. Building Style Classification on each Object

\begin{tabular}{|c|c|c|c|c|c|}
\hline \multirow[b]{2}{*}{ Research Object } & \multirow[b]{2}{*}{$\begin{array}{l}\text { Building } \\
\text { Function }\end{array}$} & \multicolumn{4}{|c|}{ Building Style } \\
\hline & & $\begin{array}{c}\text { Indische } \\
\text { Empire } \\
\text { Style }\end{array}$ & $\begin{array}{l}\text { Voor } \\
1900\end{array}$ & $\begin{array}{c}\text { De Stilj } \\
\text { (1930s) }\end{array}$ & Gothic \\
\hline City Museum & $\begin{array}{c}\text { Cultural } \\
\text { Facilities }\end{array}$ & $\sqrt{ }$ & & & \\
\hline SDK Mater Dei & Education & & & $\sqrt{ }$ & \\
\hline Red Church & Worship & & & & $\sqrt{ }$ \\
\hline SDN Tisnonegaran I Office & Education & & $\sqrt{ }$ & & \\
\hline House No. 48 & Dwelling & & & $\sqrt{ }$ & \\
\hline House No. 45 & Dwelling & & & $\sqrt{ }$ & \\
\hline House of Bank Mandiri Head Officer & Dwelling & & & $\sqrt{ }$ & \\
\hline House of Red Church Priesthood & Dwelling & & & $\sqrt{ }$ & \\
\hline House No. 25 & Dwelling & & $\sqrt{ }$ & & \\
\hline House No.63 & Dwelling & $\sqrt{ }$ & & & \\
\hline
\end{tabular}

The results obtained at the colonial building in the Suroyo corridor of Probolinggo City were dominated by the De Stilj building style (1930s). This building style emphasizes the play of building volume in the form of a cube with brick or concrete material. The decoration styles of this building can be said to be minimal, even in the gevel section which does not have the slightest style or ornamentation and most of the 
building is dominated by white. This can be seen in several houses that dominate the style of this building. The next building style dominance is found in the 19oor Voor style building which has the characteristic of a column pillar that is changed to a smaller or longer iron material and there is the addition of eaves / liufels using corrugated zinc. This style is found in the Tisnonegaran I SDN office building and House No. 25. In addition, two other buildings are in the Indische Empire Style style in residential and entertainment / cultural functions. This style can be seen visually from the column elements that are round and stand firm and made of Greek-style stones. Meanwhile, other colonial buildings are red work that is thick with Gothic-style architecture.

The seven aspects above can represent the visual character in terms of the facade elements of colonial buildings in the corridor of Jalan Suroyo, Probolinggo City. Based on this description, it can be explained in detail about the form, material, to the explanation of the details of each element of the facade. (Table 2).

Table 2. Classification based on Facade Elements

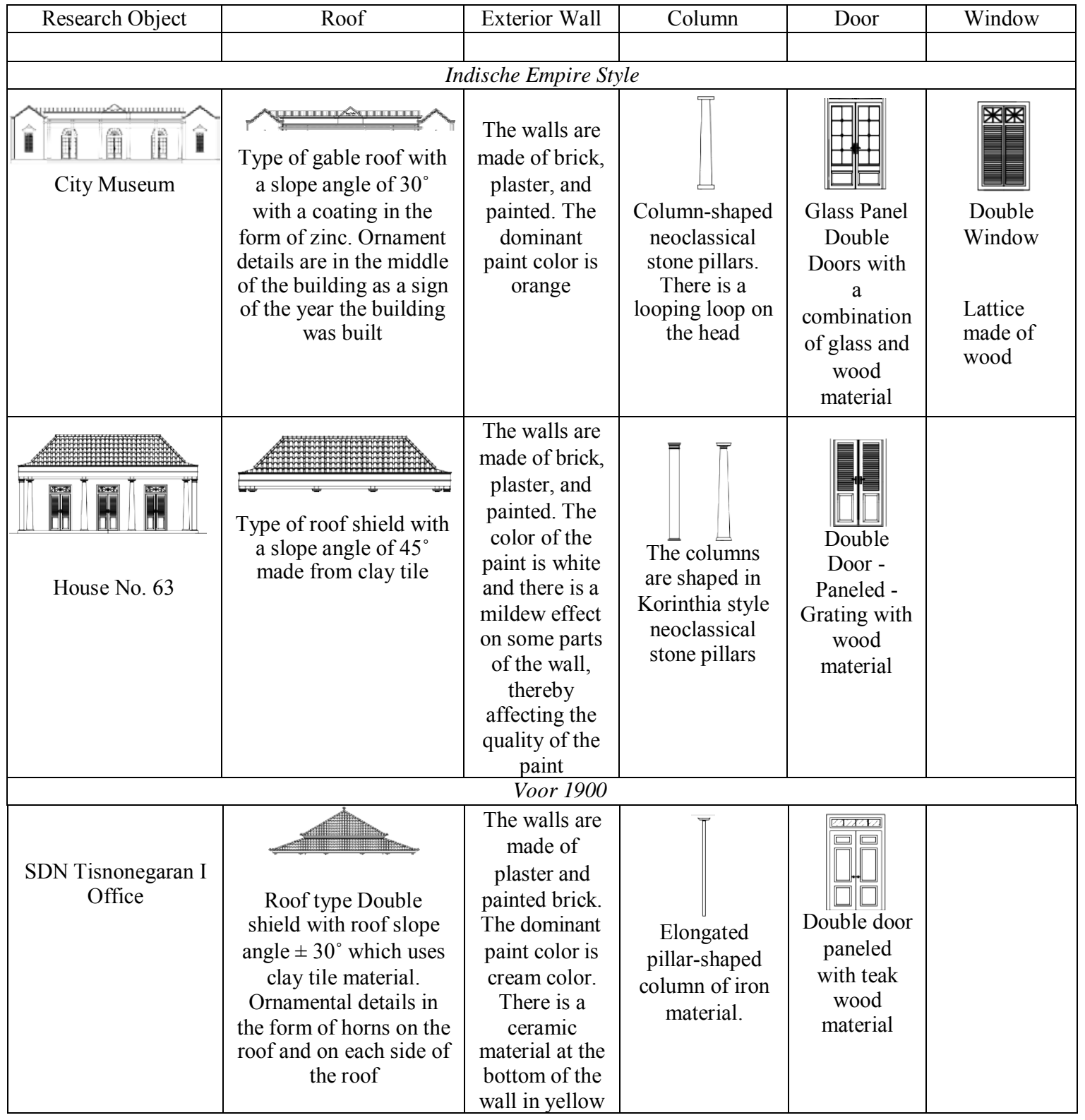


Visual Character of Colonial Building Facade in Suroyo Street Corridor, Probolinggo City Indonesia

Adita Ronarizkia' Novi Sunu Sri Giriwati

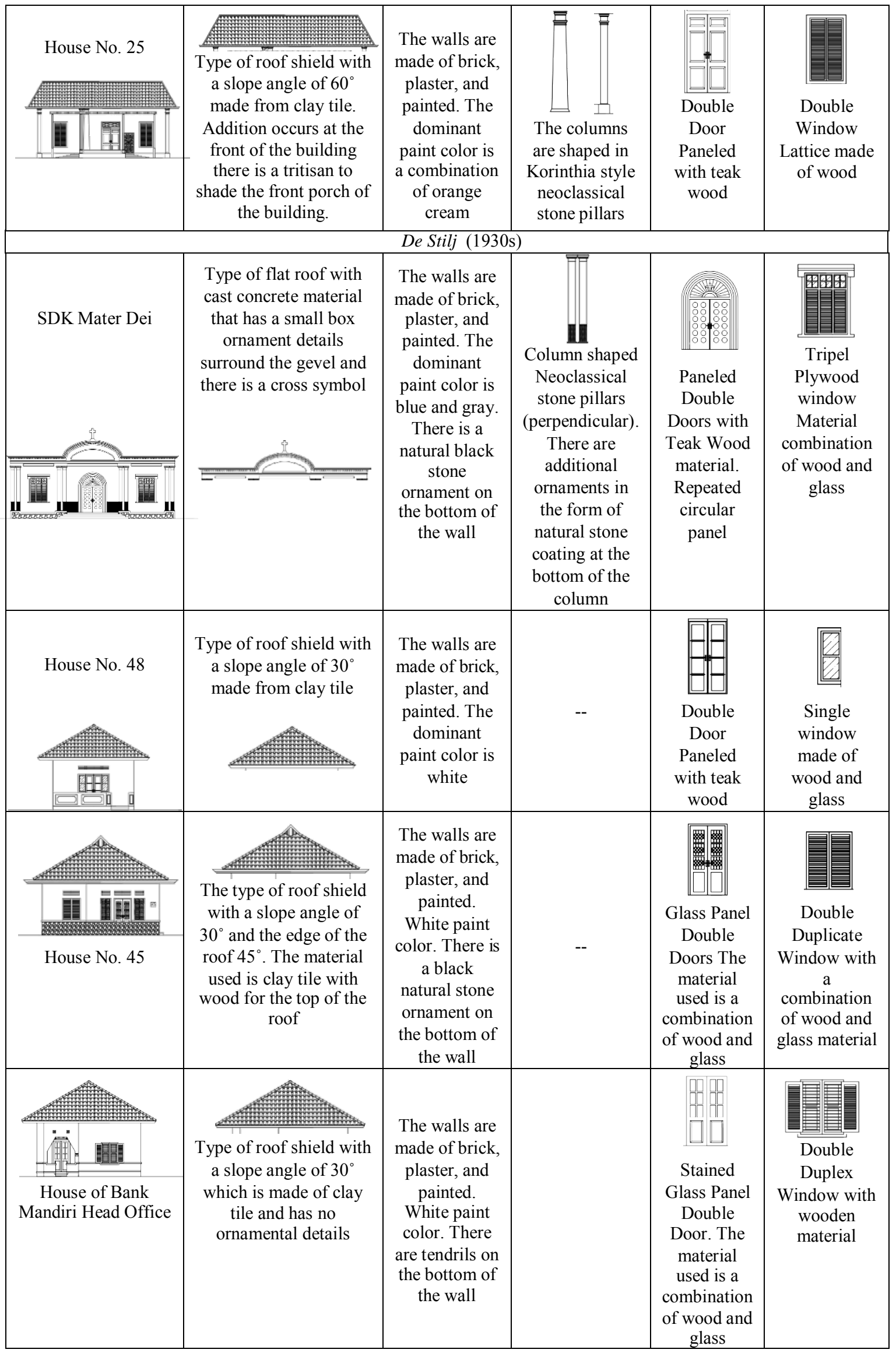


LOCAL WISDOM, Vol. 12 No. January 2020

Local Wisdom Scientific Online Journal

\begin{tabular}{|c|c|c|c|c|c|}
\hline $\begin{array}{c}\text { House Of Red } \\
\text { Church Priesthood }\end{array}$ & $\begin{array}{l}\text { Type of roof shield with } \\
\text { a slope angle of } 30^{\circ} \\
\text { made from clay tile }\end{array}$ & $\begin{array}{l}\text { The walls are } \\
\text { made of brick, } \\
\text { plaster, and } \\
\text { painted. } \\
\text { White paint } \\
\text { color. }\end{array}$ & - & $\begin{array}{c} \\
\text { Glass Panel } \\
\text { Double } \\
\text { Door with a } \\
\text { combination } \\
\text { of wood and } \\
\text { glass } \\
\text { material }\end{array}$ & $\begin{array}{c}\text { Leuble } \\
\text { Window } \\
\text { Wattice made } \\
\text { of wood }\end{array}$ \\
\hline \multicolumn{6}{|c|}{ Gothic } \\
\hline Red Church & $\begin{array}{l}\text { Type of gable with zinc } \\
\text { cover material which } \\
\text { has a slope angle of } \pm \\
45^{\circ}-60^{\circ} \text {. Ornament } \\
\text { details are the tower } \\
\text { and ventilation holes } \\
\text { made of glass engraving } \\
\text { on the gevel }\end{array}$ & $\begin{array}{l}\text { The walls use } \\
\text { corrugated } \\
\text { zinc which is } \\
\text { painted. The } \\
\text { overall paint } \\
\text { color is red } \\
\text { for the walls }\end{array}$ & -- & $\begin{array}{l}\text { Door } \\
\text { Paneled } \\
\text { with teak } \\
\text { wood. There } \\
\text { are vertical } \\
\text { rectangular } \\
\text { panels }\end{array}$ & $\begin{array}{l}\text { Gothic Single } \\
\text { Window with } \\
\text { combination } \\
\text { of wood and } \\
\text { stained glass }\end{array}$ \\
\hline
\end{tabular}

\section{Factors that influence Changes in Visual Character}

Changes in visual character that occur are caused by several factors, including factors that were caused by humans and factors that are not related to humans. Some buildings in the Suroyo corridor in Probolinggo City have experienced changes due to changes or changes in ownership, so that in maintaining and preserving certain elements in the building is not properly implemented. This is indicated by building house no. 25 which experienced the addition of a roof element attached to the original roof. The addition is made of corrugated zinc material which serves as the shelter for the terrace. Another change in character caused by human factors is at the Museum of the City of Probolinggo. The museum is experiencing a change in the color of paint which is dominated by hot colors such as orange, to match the themes and concepts that have been planned by the government.

Other factors that influence changes in the visual character of buildings are natural factors and other cultural influences. This was proven in house no. 63 with the roof and walls experiencing color changes caused by natural enviroment, climate and the growth of mocroorganism (moss) so that the color that was originally white illustrates the character of colonial buildings, has now changed to white color accompanied by a black pattern. (Figure 8)

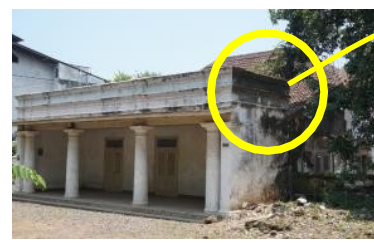

color changes caused by the growth of mocroorganism

(moss)

Figure 8. The changes to some elements of house number 63 


\section{Visual Character of Colonial Building Facade in Suroyo Street Corridor, Probolinggo City Indonesia}

\section{Conclusion}

Adita Ronarizkia Novi Sunu Sri Giriwati

The visual character of the building facade formed is largely a character that characterizes colonial buildings. The aspect of building mass of the entire research object produces a dominant rectangular mass (ratio of building width higher than building height) with a single mass category. The character of the roof element is dominated by a shieldshaped roof that uses clay tile material. The exterior wall of the building has a type of wall covering with plaster coated with paint with a thickness of $15 \mathrm{~cm}$. This is included in the characteristics of Dutch colonial buildings in Indonesia. The door element that dominates is the double paneled door with wood material. Meanwhile, the window is dominated by a double window paneled grille and is equipped with a scoping material in the form of a combination of wood and glass. The door and window elements are also included in the character of the Dutch colonial structure with a vertically stronger element than the horizontal. Then the building column elements that have the shape of the dominance of plaster pillars in the paint that cone upwards. The symmetrical facades of most of the colonial buildings on Suroyo Street, Probolinggo City have symmetrical or balanced shapes.

Ten buildings on Suroyo Street, Probolinggo City are included in the original visual character with the style of De Stilj (1930). This is in accordance with the conditions of the colonial building elements in this corridor which are simple and not full of decorative accents. Although most of the building components are still on its original condition, there are also some buildings that change with the addition of elements shape and materials used. Changes with the addition and replacement of material in some of these elements do not change the shape and facade as a whole, so that the colonial buildings in the Suroyo Street Corridor area are still maintained and are still in the category of controlled and directed changes. Factors that cause changes in the visual quality of buildings in this corridor are climate and human factors as building owners.

\section{REFERENCES}

Cahyani, R., L. D. Wulandari and Antariksa (2014) 'Simetrisitas Sebagai Kosmologi Ruang Jawa Pada Rumah Kolonial Di Kampung Bubutan Surabaya', Tesa Arsitektur, XII(2), pp. 141-155.

Estin, N., Antariksa and N. Suryasari (2016) 'Karakteristik Visual Bangunan Kolonial Belanda Di Jalan Pemuda Depok', arsitektur e-Journal, 10(2), pp. 52-59.

Fajarwati, A. N., Antariksa and N. Suryasari (2011) 'Pelestarian Bangunan Utama Eks Rumah Dinas Residen Kediri', arsitektur e-Journal, 4(2), pp. 85-105.

Hadi Dharma, L. A., Antariksa and E. Basuki Kurniawan (2014) 'Pelestarian Kawasan Dan Bangunan Kuno Bersejarah Pusat Kota Probolinggo', arsitektur e-Journal, 7(2), pp. 102-114.

Handinoto (1996) 'Perkembangan Kota Malang pada Jaman Kolonial (1914-1940)', (September).

Handinoto (1997) 'Bentuk Dan Struktur Kota Probolinggo Tipologi Sebuah Kota Administratif Belanda', DIMENSI 23/ARSITEK, pp. 1-22. 
Handinoto (2010) Arsitektur dan Kota-kota di Jawa pada Masa Kolonial. Yogyakarta: Graha Ilmu. Krier, R. (2001) Komposisi Arsitektur. Jakarta : Erlangga.

Kurniawan, A. (2017) 'Identifikasi Bangunan Kolonial untuk Pelestarian Fasade di Jalur Belanda Kota Singaraja Bali', in Seminar Nasional Arsitektur dan Tata Ruang (SAMARTA), Bali-2017, pp. 17-24.

Kurniawan, A., R. Salain and C. Trimarianto (2015) 'Konservasi Fasade Bangunan Kolonial di Jalur Belanda, Kota Singaraja, Bali', SPACE, 2(2), pp. 149-168.

Misavan, D. F. and B. J. B. Gultom (2014) ‘Pengaruh Pembaruan Fasad Bangunan Terhadap Karakter Visual Kawasan Studi Kasus: Jalan Tanjungpura Pontianak', Langkau Betang, 1(2), pp. 1-16.

Piutanti, R. (2019) 'Typology of Fasade Building in Kayu Tangan Street Corridor, Malang City', LOCAL WISDOM, 11(2), pp. 107-120.

Soekiman, D. (2000) Kebudayaan Indis dan Gaya Hidup Masyarakat Pendukungnya di Jawa. Yayasan Bentang Budaya, Yayasan Adikarya Foundation dan The Ford Foundation.

Sudarwani, M. 1972. (1972) 'Karakter Visual Koridor dalam Pembentukan Image Kota', Penelitian Arsitektur Universitas Diponegoro Semarang.

Sukarno, P. G., Antariksa and N. Suryasari (2014) 'Karakter Visual Fasade Bangunan Kolonial Belanda Rumah Dinas Bakorwil Kota Madiun', Jurnal Arsitektur NALARs, 13(2), pp. 99-112.

Thamrin, D. (2010) 'Tata Bangunan Rumah Tinggal Daerah Pecinan di Kota Probolinggo Jawa Timur', Dimensi Interior, 8(1), pp. 1-14.

Wiyatno, L. H. D. A., Antariksa and E. B. Kurniawan (2014) 'Pelestarian Kawasan dan Bangunan Kuno Bersejarah Pusat Kota Probolinggo', Planning for Urban Region and Environment, 3(3), pp. 73-80. 